\title{
WOMEN'S CAREER PATHS IN HUNGARIAN HIGHER EDUCATION IN THE LIGHT OF THE BOLOGNA PROCESS
}

\author{
NŐI KARRIER-UTAK A MAGYAR FELSŐOKTATÁSBAN A \\ BOLOGNA FOLYAMAT TÜKRÉBEN
}

\author{
Eszter BORSOS ${ }^{a}$, Ádám Gergő KISS \\ a Address: 1029 Budapest, Huba vezér utca 54., phone: +36 3045508 47, e-mail: \\ eszter.borsos5@gmail.com \\ b Address: 2100 Gödöllő, Bercsényi Miklós u. 13, phone: +36 $30 \quad 6586$ 048, e-mail: \\ kissadamgergo@gmail.com
}

Cite this article: Borsos, E, Kiss, A. G. (2015). Women's Career Paths in Hungarian Higher Education in the Light of the Bologna Process. Deturope, 7, 2: 206-219

\begin{abstract}
In our research we investigate the Hungarian higher education, which has undergone some significant transformation over the past decades. The Bologna process has fundamentally transformed our higher education: most of the previous single and undivided trainings were transformed into a two or threestepped ones.

After the previous regime the way opened for the founding of private colleges and their accreditation, which generated, again, a number of changes: the financing side showed novelties. This can be interpreted as a response to the state's strategy that it intends to withdraw from the financing of higher education.

As a result, those young people are also included in the form of fee-paying system, who did not have access to higher education because of the narrow academic admissions. At the same time, since the nineties, women became over represented in higher education on the student side.

However, to date there are few women in higher education on the management side.
\end{abstract}

Keywords: Higher education, women's career, learning motivations, Bologna process, leader

\section{Kivonat}

Kutatásunkban az elmúlt évek, évtizedek alatt számos átalakuláson átesett felsőoktatást vizsgáltuk. A Bologna folyamat alapjaiban alakította át felsőoktatásunkat: kettő, illetve háromlépcsőssé alakult az addigi egységes, osztatlan képzések többsége. A rendszerváltás után megnyílt az út a magánfőiskolák alapítása, valamint akkreditációja előtt is, mely ismételten számos változást generált: a finanszírozás oldaláról újdonságok mutatkoztak. Ezt válaszreakcióként is értelmezhetjük azon állami magatartásra, mely szerint a mindenkori állam egyre inkább kivonul a felsőoktatás finanszírozásából, támogatásából. Ennek eredményeképp olyan fiatalok is "bekerültek a rendszerbe" költségtérítéses formában, akik eddig az állami intézmények szűk keretlétszámai miatt nem fértek volna be. Ezzel egyidejüleg a kilencvenes évektől fogva a nők felülreprezentáltakká váltak a felsőoktatásban a hallgatói oldalon. Azonban a mai napig arányaiban kevés nőt találunk a felsőoktatásban vezetői oldalon.

Kulcsszavak: Felsőoktatás, női karrier, tanulási motivációk, Bologna folyamat, vezető 


\section{INTRODUCTION}

Several studies have already reported on higher education's expansion following the transformation of regime, which we can examine in several dimensions.

First, we need to talk about the drastic increase in the number of students - as between 1990 and 2004; the 20-24 aged group (potentially involved in receiving academic education) age ratio grew from 15.5 to $45 \%$ from the total population. (Szemerszki 2004, p. 56.)

On the other hand, an explosive change had happened in the number of higher education institutions. Private higher educational institutions appeared in the form of private colleges and universities.

In the present study, we do not differentiate institutions established by the church or privately; all institutions are defined as private which are not public. It is not relevant to our topic to look beyond the operation of state-managed institutions.

\section{OBJECTIVES AND METHODS}

Our aim is to clarify the potential aspects of some of these trends. In this part we investigate the potential gender gap between men and women in leading positions. For this we use interviews with ladies in a leading position in higher education (Head of Department, Head of Department, Rector, Vice-Rector) and online questionnaire with current students. Our online questionnaires we will be processed using the SPSS software package. We also had a look at the rate of women in the newly introduced chancellor system in the Hungarian higher education.

\section{RESULTS}

\section{Students - Professors ratio}

Since the academic career today is hard to imagine without scientific grade, we should first turn to consider that what changes have taken place - in terms of male, female ratios - among the students. We know from the 1990s that women are over-represented in higher education, at the student's side. (www.felvi.hu)

However it is worth to make additional researches as we go forward through the different levels of higher education. Unfortunately, there is still cannot be found newer statement than this one below, that shows the data only until 2011, but in our opinion, we could not observe relevant differences in the analysis of the data later. 
Figure 1 The number of students taking a part in a doctoral (PhD, DLA) training, 2008-2011

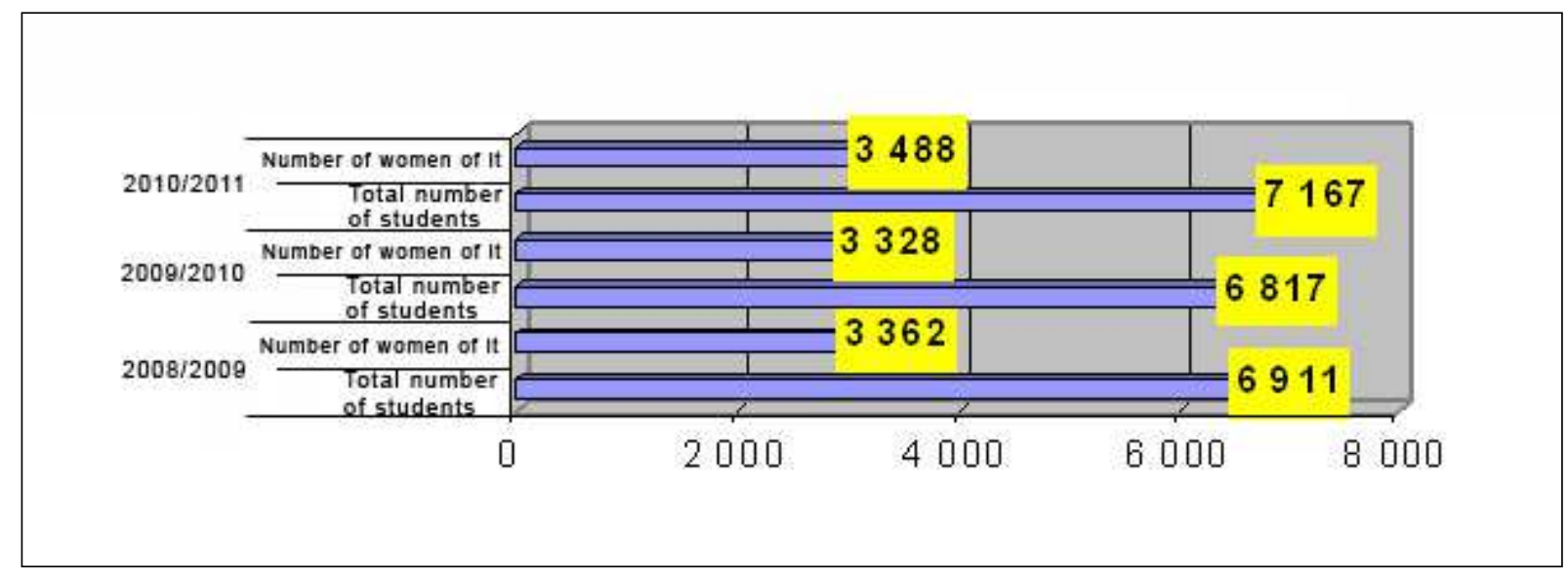

Source: Statisztikai Tájékoztató-Felsőoktatás (KSH, 2011.)

As you can see in the graph above, at the beginning of the $21^{\text {st }}$ century a significant increase happened in the proportion of women among doctoral students; practically we can say that half of the doctoral program participants are women. In our opinion this could be a promising fact considering the future, because the gender gap cannot be seen at this side. However, as we move forward on the scientific careers ladder, the proportion of women is deteriorating more and more. In other words, fewer and fewer women can be seen as an associate professor, professor or as a member of the Hungarian Academy of Sciences, so at these areas we could feel male dominance. (Riba, 2011)

Of course, it would be worth examining the higher educational career and the researcher, academic career separately. However, it is not separated from each other in the everyday life, because academic research institutions expect their "employees" to carry out major teaching activity also. Not to mention the fact that professors can be found among the academic members and in various committees and academics. This imposes a "bigger burden" to women again (compared to their man companions), because of the already mentioned "double burden" (work and family) is combined here with research and teaching activities. "A survey in the United States exemplifies the inequality also. (Davies, Holloway 2004, p.16.) Researchers work an average of 53.5 hours a week, from this the administrative work takes 17-18 hours, and most of the research work take place in the evening or on weekends. Women work more at all levels than men, and do more administrative work. An average female university professor's working hours are 64.5, while a man university teacher's working hours are only 58.6 hours per week." (Papp, 2007, p.35.) 
The so-called "career gap" is widening. Examining all of the higher educational institutions in Hungary nowadays we find that we have 11 female and 21 male rectors, and 56 female deans to the 106 male deans.

Figure 2 Rector - Dean's positions and distribution in Hungary - by gender

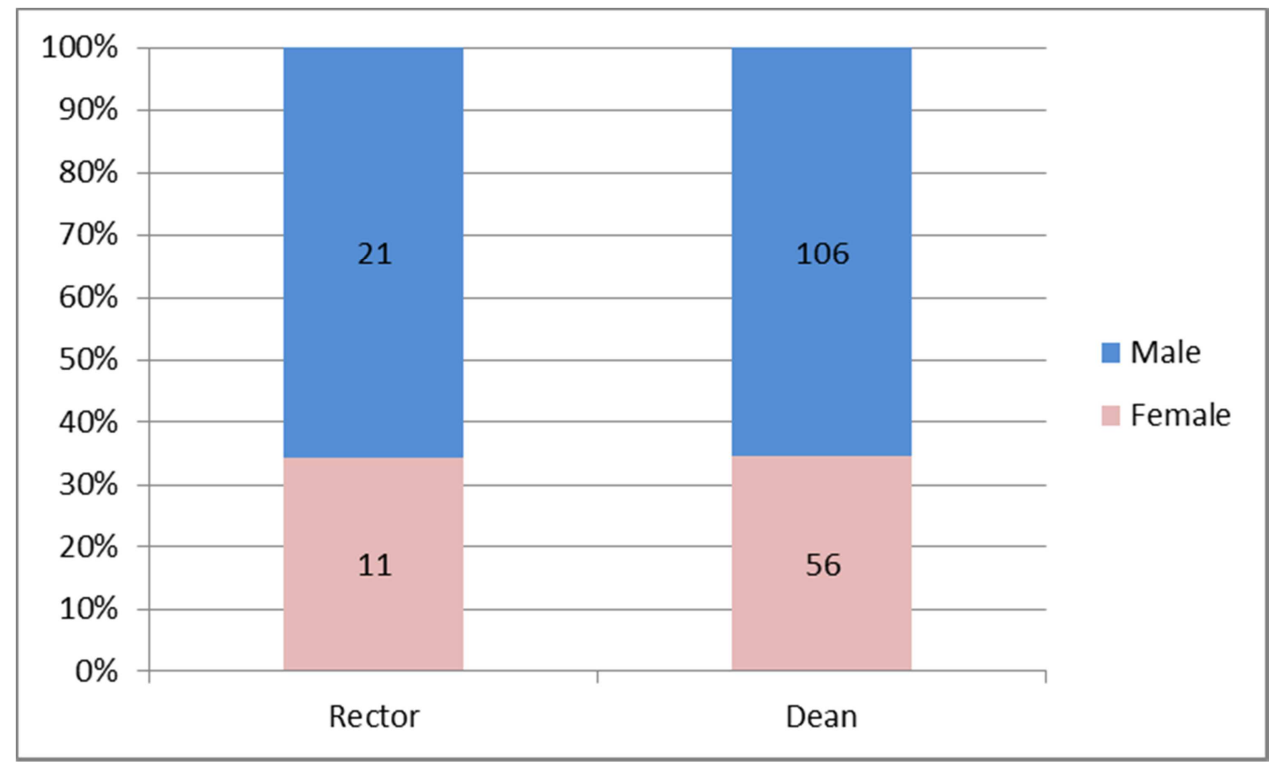

Source: Own edition based on www.mrk.hu, 2014

The chancellery system, which was been introduced this year, has not made "revolutionary changes" in the ratio of man and female leaders. From the currently elected 24 chancellors only 3 are women. (http://eduline.hu/felsooktatas/2014/10/31/teljes_kancellari_nevsor_5R8MO8)

\section{Experiences of the previous interviews}

The interviewees were at least senior lecturer women, but we could also have interviews with women rectors.

For us, it was shocking that even though they have a beautiful bright career of their own, when we asked about what advise would they give to their young women colleges to earn similar success, or what they think of the change in women leaders' under-representation in the near future, surprisingly pessimistic responses were given. Some of them said that this is a very slow process (because of the social stereotypes, the traditional approach); she sees in 2030 years perspective a few percentage of growth. Almost all of the respondents pointed out, that the discipline is very decisive, because, while in the humanities or social sciences we 
could see a lot of ladies, in the world of natural and technical sciences their occurrence is rare. (Noszkay-Borsos, 2014)

The abovementioned seem to be true on the EU level as well: "Only 33\% of European researchers, $20 \%$ of European university professors and $15 \%$ of the heads of institutions of higher education are women. In 2010, female students (55\%) and a graduate of the proportion $(59 \%)$ were higher than the proportion of male students, but among doctoral and doctoral degree holders' men were represented at a higher rate (the proportion of women was $49 \%$ and $46 \%$ ). In regard to the academic career ladder, women who earned a doctorate degree are $44 \%$ in the first level of academic career researchers, but the portion of women researchers working in the uppermost however, is only $20 \%$. The low number of women in science and engineering fields is even more striking." (http://europa.eu/rapid/press-release_IP-13303_hu.htm)

It was also surprising to us that the responders almost always emphasized the special domestic "adverse selective" practices which they faced several times during their careers: the fact that male counterparts are usually addressed by their rank, or position in each case, (Prof. Mr. Dean, Mr. Rector), but they often had 'only' first names.

\section{Results of the research}

As we saw earlier, women are underrepresented in Hungarian higher education management layer. We believe that the "roots" should be examined in order to gain a more nuanced picture of the situation of women in higher education (either leaders or student status). It means an examination of the motivations, which are chosen on the basis of further education for young people in higher education. That is why we think it is important to ask the question: why do students learn? Our topic is relevant to the question, because the leaders of future are the students of today.

In our study, we asked students in higher education institutions. This study is considered only as a preliminary test, so we chose one of the simplest ways to reach students: the social network. The questionnaire, in the form of self-filled forms, was available electronically.

113 people filled out our questionnaire. From the people who filled it 21 were male and 92 were female. The mean age was 25-year-olds (born in 1989). The age difference between genders was only two years. 
Table 1 What type of town you live in currently

\begin{tabular}{|c|c|c|c|c|c|c|c|}
\hline & Village & Capital & Municipality & $\begin{array}{l}\text { Foreign } \\
\text { capital }\end{array}$ & $\begin{array}{l}\text { City with } \\
\text { county } \\
\text { rights }\end{array}$ & City & Total \\
\hline Gender Men & 2 & 6 & 2 & 0 & 4 & 7 & 21 \\
\hline Women & 2 & 49 & 7 & 1 & 7 & 26 & 92 \\
\hline Total & 4 & 55 & 9 & 1 & 11 & 33 & 113 \\
\hline
\end{tabular}

Source: Own edition, 2014

Table 1 shows that the majority of those filling live in the capital. The people living in cities and towns and the cities with county rights follow this. More than half of women live in the capital, while majority of men are urban residents.

Word clouds in Annex 1 and 2 show the institutions of the interviewed students. It is unequivocal that most interviewed men and women are from the Szent István University. In case of women we see more institutions than in the case of men. This may be a result of the different ratio of the respondents.

Table 2 Type of education

\begin{tabular}{|c|c|c|c|c|c|c|}
\hline & BSc & MSc & $\begin{array}{l}\text { Undivided } \\
\text { education }\end{array}$ & $\mathrm{PhD}$ & $\begin{array}{l}\text { Postgraduate } \\
\text { specialist } \\
\text { training } \\
\text { course }\end{array}$ & Total \\
\hline Gender Men & 9 & 7 & 4 & 1 & 0 & 21 \\
\hline Women & 40 & 38 & 6 & 7 & 1 & 92 \\
\hline Total & 49 & 45 & 10 & 8 & 1 & 113 \\
\hline
\end{tabular}

Source: Own edition, 2014

We can see that the most students are in BSc. the question is that if the group of BSc students were the most numerous, what could have caused the "high" mean age? Perhaps the answer is found in the form of education. 
Table 3 Form of education

Source: Own edition, 2014

\begin{tabular}{|c|c|c|c|}
\hline & $\begin{array}{l}\text { Correspondence } \\
\text { course }\end{array}$ & \begin{tabular}{|l|} 
Full-time \\
course
\end{tabular} & Tota \\
\hline Gender Men & 3 & 18 & 21 \\
\hline Women & 19 & 73 & 92 \\
\hline Total & 22 & 91 & 113 \\
\hline
\end{tabular}

Analysis of the results revealed that most of the interviewed students were involved in fulltime course. Therefore, further clarification is needed to find out the reason behind the results.

\section{Results of the questionnaire survey}

Figure 3 Motivation scale of college studies $(n=113)$

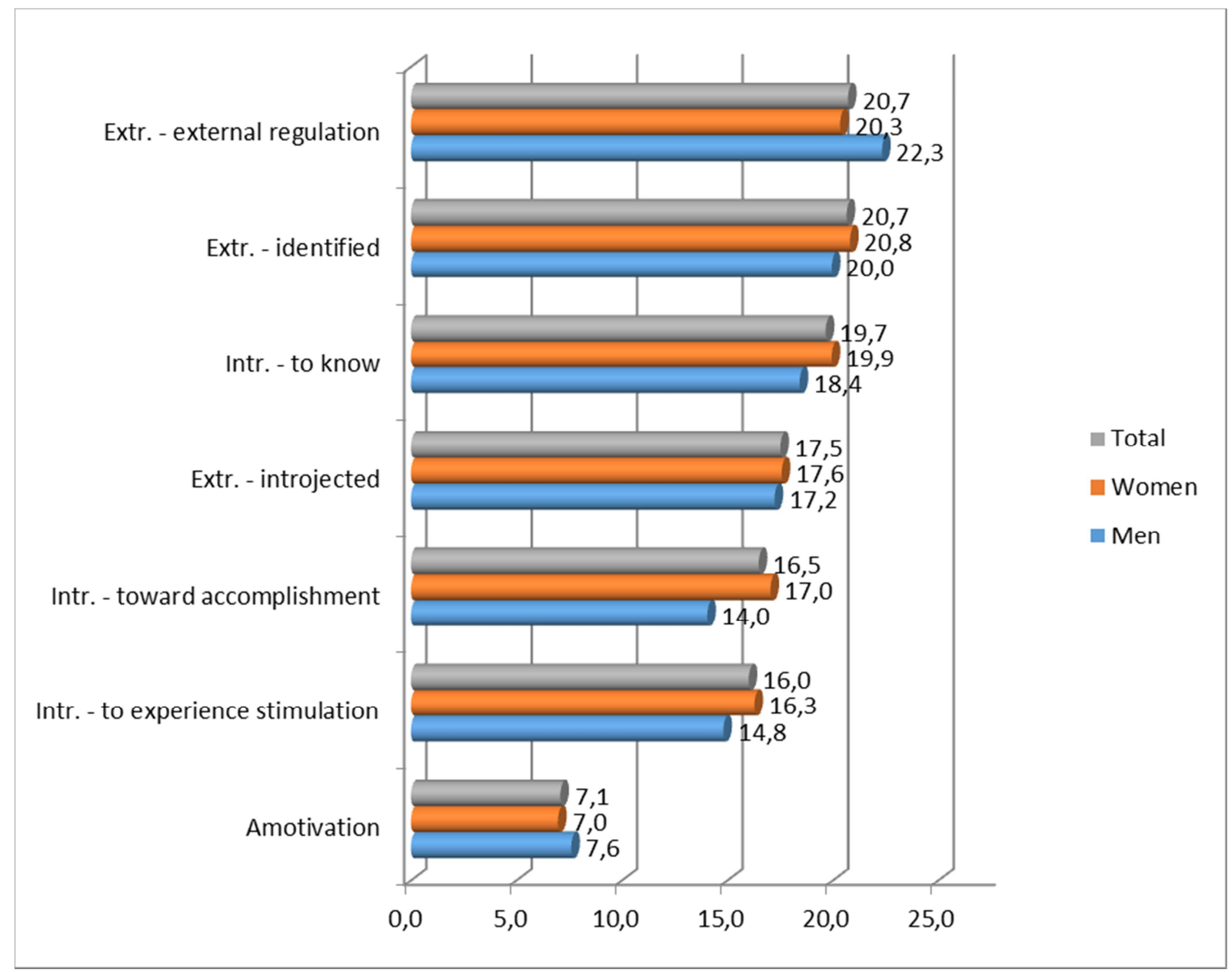

Source: Own edition, 2014

Figure 3 shows the results of the motivational questionnaire. We can see that the primary motivation for learning is usually some external factor. For men, we can see that the average 
value is higher in the primary motivator. In the second we can find an extrinsic motivator also. From the internists none could get higher than the third place, only one ("to know"). As we can see we do not find large differences between the genders. Men and women selecting the motivational factors in the same proportion, despite the fact that the number of women was in the majority.

Figure 4 Other learning motivations $(\mathrm{n}=113)$

Because I think university study is joyful

Because parents / family expect this from me

Because it is necessary for future academic leader career

Because I want to build social capital for later career, which I imagine in the university senior management

Because of the expansion of higher education I had the opportunity for it

Beacause I would like to work as researchers in higher education

Because I plan my future in higher education as a professor

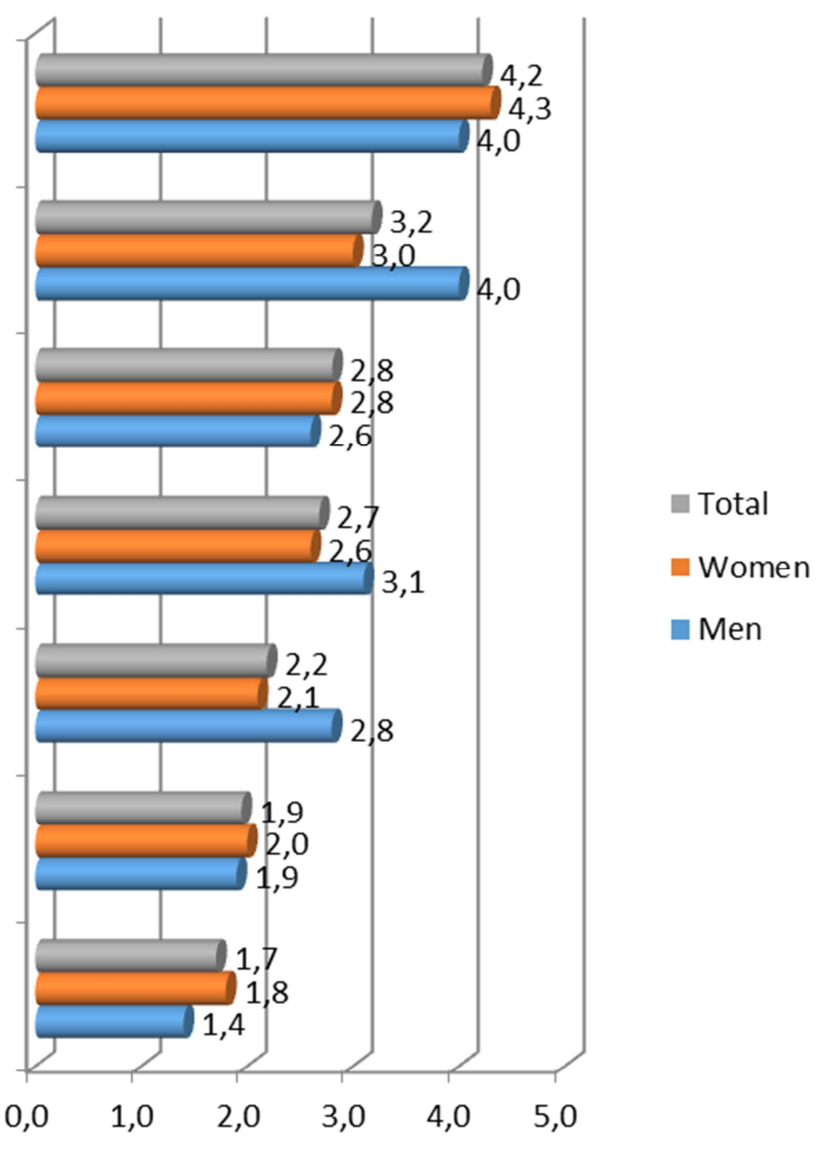

Source: Own edition, 2014

In our questionnaire we asked other motivational factors in addition to the motivators offered by AMS. At the first place the students think university studies are joyful. However, this response raises more questions (Why is it joyful? What can be a source of joy? etc.), which are the subjects of further investigation. In the second place we find the parents as "incentive" factors. Based on this, we can conclude that the parents are in the background of the previously seen primary learning motivation (external regulation).

In the last place there are those questions that are related to academic careers. We can see that the respondents did not envision a career in higher education journey. 
In this study, we tried to look for correlations between responses.

Table 4 Correlations (men)

\begin{tabular}{|l|r|r|}
\hline & $\begin{array}{r}\text { Because I } \\
\text { would like to } \\
\text { work as a } \\
\text { researcher in } \\
\text { higher } \\
\text { education }\end{array}$ & $\begin{array}{r}\text { Because of the } \\
\text { expansion of } \\
\text { higher } \\
\text { education I had } \\
\text { the opportunity } \\
\text { to do it }\end{array}$ \\
\hline $\begin{array}{l}\text { Because I would like to work Pearson Correlation } \\
\text { as a researcher in higher Sig. (2-tailed) }\end{array}$ & 1 &, $607^{* *}$ \\
education & N &, $607^{* *}$ \\
\hline $\begin{array}{l}\text { Because of the expansion of Pearson Correlation } \\
\text { higher education I had the Sig. (2-tailed) } \\
\text { opportunity to do it }\end{array}$ &, 004 \\
\hline
\end{tabular}

**. Correlation is significant at the 0.01 level (2-tailed).

Source: Own edition, 2014

The correlation table shows that the respondent men who imagine the future career in the higher education believe they have an opportunity because the expansion of higher education. For women the same issue was examined as well.

Table 5 Correlations (women)

\begin{tabular}{|l|r|r|}
\hline & $\begin{array}{r}\text { Because I } \\
\text { would like to } \\
\text { work as a } \\
\text { researcher in } \\
\text { higher } \\
\text { education }\end{array}$ & $\begin{array}{r}\text { Because of the } \\
\text { expansion of } \\
\text { higher } \\
\text { education I had } \\
\text { the opportunity } \\
\text { to do it }\end{array}$ \\
\hline $\begin{array}{l}\text { Because I would like to work Pearson Correlation } \\
\text { as a researcher in higher Sig. (2-tailed) }\end{array}$ & $\begin{array}{r}1 \\
\text { education }\end{array}$ &, $425^{* *}$ \\
\hline $\begin{array}{l}\text { Because of the expansion of Pearson Correlation } \\
\text { higher education I had the Sig. (2-tailed) } \\
\text { opportunity to do it }\end{array}$ &, 000 \\
\hline
\end{tabular}

**. Correlation is significant at the 0.01 level (2-tailed).

Source: Own edition, 2014

In the case of women we could not find a strong correlation between the answers, and this relation is not even significant, as seen in the case of males. 
Table 6 Correlations (women)

\begin{tabular}{|c|c|c|}
\hline & $\begin{array}{c}\text { Because of the } \\
\text { expansion of } \\
\text { higher } \\
\text { education I had } \\
\text { the opportunity } \\
\text { to do it }\end{array}$ & $\begin{array}{l}\text { Because I want } \\
\text { to build social } \\
\text { capital for later } \\
\text { career, which I } \\
\text { imagine in the } \\
\text { university senior } \\
\text { management }\end{array}$ \\
\hline $\begin{array}{l}\text { Because of the expansion of Pearson Correlation } \\
\text { higher education I had the Sig. (2-tailed) } \\
\text { opportunity to do it }\end{array}$ & $\begin{array}{r}1 \\
92\end{array}$ & $\begin{array}{r}, 344^{\star \star} \\
, 001 \\
92\end{array}$ \\
\hline $\begin{array}{l}\text { Because I want to build Pearson Correlation } \\
\text { social capital for later Sig. (2-tailed) } \\
\text { career, which I imagine in } \mathrm{N} \\
\text { the university senior } \\
\text { management }\end{array}$ & $\begin{array}{r}, 344^{\star *} \\
, 001 \\
92\end{array}$ & $\begin{array}{r}1 \\
92\end{array}$ \\
\hline
\end{tabular}

**. Correlation is significant at the 0.01 level (2-tailed).

Source: Own edition, 2014

In case of women we have discovered another significant relation (even if it is only moderate), which is the relation between the expansion of higher education and the social capital acquisition.

\section{DISCUSSION}

\section{Higher education panorama}

We found the most appropriate definition in the PhD dissertation of Szemerszki Marianna to definite the concept of private higher education, which reads as follows: "The most common definition of education of any type is, which was founded only by individuals or associations, and operates within the scope of private education." (Szemerszky, 2003, p. 9.)

The expansion brought to life a particular competition also, where not only the students are those who are competing to get to a prestige higher education institution, but a sort of rivalry started between the institutions for students as well. A quite new color was brought into, until then closed, traditional higher education segment with the private institutions' elasticity and impetus.

However, the question arises whether is it a competitive situation, or perhaps it is more of specific market segmentation? In our point of view, although approximately the same age groups appears as potential future for students, these institutions seem to have become more of a complement of each other. Considering that they satisfy the needs of different market 
segments, - they segmentate their students, contemplating them as potential consumers, as well. Due to their size, their management point of view and their new institutional structure, private institutions are able to respond to the market demands, the labor market challenges and the diverse needs of the students.

However there is a trend of higher education expansion, which we cannot disregard. This is the state of the qualified professors. The increasingly stringent accreditation criteria changes in legislation and institutional growth brought to life a particular competition, which is about the right number of qualified professors. This affects and affected private and state institutions equally.

Last but not least, the introduction of the Bologna system, at the beginning of the last decade fundamentally changed the previous higher education system. By the transformation a new three-tier structure of training was introduced (basic - master - $\mathrm{PhD}$, and vocational training specializations, see e.g. MBA) instead of the previous single, undivided trainings, or in some majors (e.g., doctor or lawyer specialization), as additions.

\section{The Academic Motivation Scale (Vallerand et al., 1992)}

In accordance with the determination of McClelland (1985), the motivation is observed as the cause of the behavior. Therefore, in the study of school motivation he asks the responder who tries to find the answer to the question: "Why do you attend high school/college?" The items must be placed on a seven-point Likert scale.

The writers apply the trichotomy of intrinsic motivations. In the education research literature the intrinsic motivation to know, to acknowledge and to understand is a wellestablished phenomenon. This factor can be determined in relation to educational aspirations, such as to engage in an activity for the purpose of learning, discovery or understanding something new for the joy of experience. The example of Vallerand et al (1992) is like reading a book for the joy when you can learn something new.

The intrinsic motivation toward accomplishment, achieving something, is the second type of intrinsic motivations. The person takes part in the activity for the joy and satisfaction when trying to achieve something or create something. In this case, the focus is not primarily the result, but the access to the process.

The third type of intrinsic motivation is to experience stimulation. In this type of intrinsic motivation, the person is involved in the activities for the stimulating experiences (e.g.: sensual pleasure, aesthetic experience, as well as joy and excitement) gained by personal actions. 
The extrinsic motivation is divided into three subscales by the authors, these are: external regulation, identified and introjected motivation.

In case of external regulation people do things to avoid the punishment, and to gain rewards. Vallerand has an example for this motivation: the person who had learned during the night before the exam, because his/her parents forced him/her to do so.

In the case of introjected motivation the former external compliances are internalized and concerned. An example is a student who is studying the night before the exam, because "the people should do it."

In case of the extrensic motivation-identification, the person consciously evaluates the importance of the action. An example of this is when a student studies during the whole evening before the exam, because he/she feels that it is important to him/her.

In addition, the questionnaire also includes the examination of amotivation. Amotivation occurs when the behavior is neither extrinsic, neither intrinsic. It is associated with the sense of incompetence and the feeling of uncontrollableness. The people are disappointed in this case, they begin to question why they are involved in education, which can ultimately lead to drop-out.

\section{CONCLUSION}

\section{Summary, future plans}

In conclusion, we can say that our survey is only a rudimentary exploratory research but still resulted a number of new information, which encourages us to continue the research.

In the following, we want to expand our questionnaire survey and conduct interviews because of a larger and more accurate sampling. The future results would be representative in regard to the Hungarian higher education. Our goal is to continue our activities with in-depth researches in the subject, and the expansion of the questionnaires to specific institutions. 
ANNEX

Annex 1. Institutions (men)

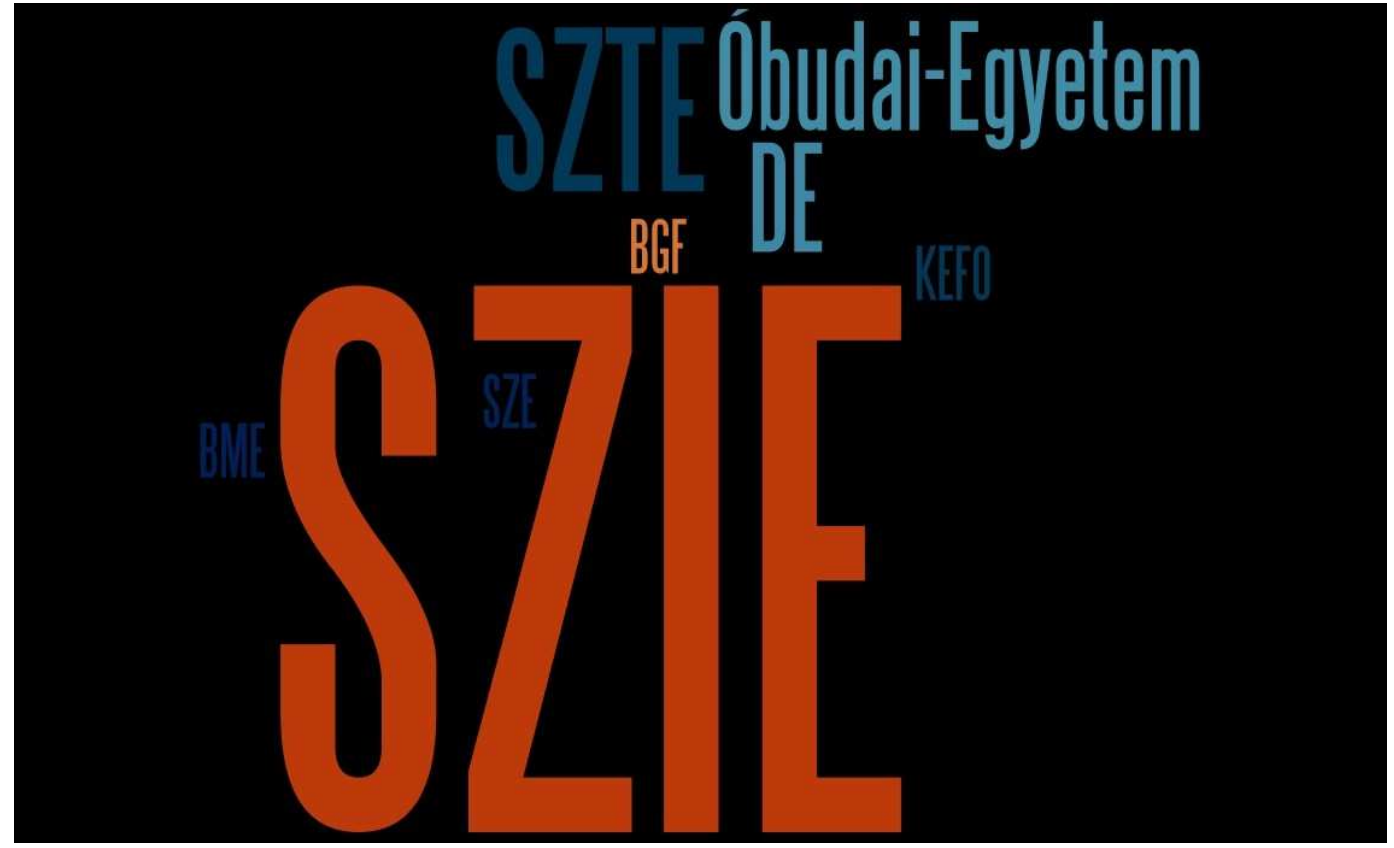

Annex 2. Institutions (women)

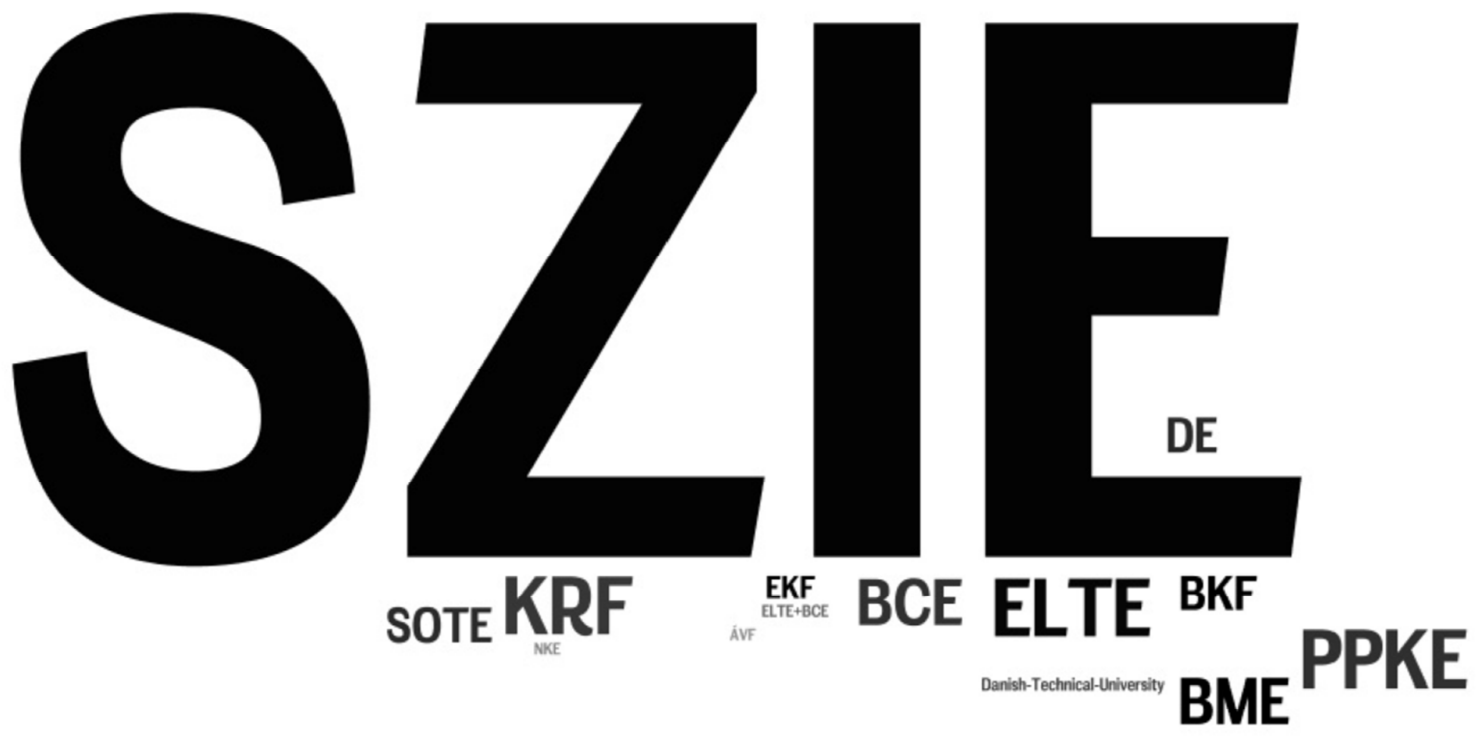




\section{REFERENCES}

Davies, C. - Holloway, P. (2004): Troubling Transformations: Gender Regimes and Organizational Culture in the Academy In Morley, L. - Walsh, V. eds: Feminist Academics: Creative Agents for Change, Taylor \& Francis Group, Chapter 1 p. 7-21. IN: Papp Eszter: A nők és férfiak közti esélyegyenlőség a kutatás-fejlesztésben Magyarországon nemzetközi összehasonlításban. (Equality between women and men in research and development in Hungary in an international comparison. PhD.Thesis) PhD.-értekezés, 2007

Itt a teljes lista: ők lesznek az egyetemi-föiskolai kancellárok. (There is the full list: they are the university and college chancellors) Retrieved: November 7, 2014 from http://eduline.hu/felsooktatas/2014/10/31/teljes_kancellari_nevsor_5R8MO8

Európai Bizottság - Sajtóközlemény (2013. április 5): Az EU-ban a nők továbbra is alacsony számban vannak jelen a kutatásban. (European Comission - Press release (04. 05. 2013.): Report shows women still under-represented in EU research.) Retrieved october 10, 2014 from http://europa.eu/rapid/press-release IP-13-303 hu.htm

McClelland, J. L. (1985). Distributed models of cognitive processes. In D. Olton, E. Gamzu, \& S. Corkin (Eds.), Memory Dysfunctions: An integration of animal and human research. New York: New York Academy of Sciences.

Noszkay, E - Borsos, E (2014): Paradigm changes in higher education along women's leadership and academic career path, In: Managerial Challenges of the Contemporary Society, volume 7 , issue 1

Papp, E (2007): A nők és férfiak közti esélyegyenlőség a kutatás-fejlesztésben Magyarországon nemzetközi összehasonlításban. PhD értekezés (Equality between women and men in research and development in Hungary in an international comparison. PhD.Thesis)

Riba, I (2011): Keresd a nőt! Nemek és esélyek. (Look for the women! Gender and chances) HVG 2011/34

Statisztikai Tájékoztató - Felsőoktatás (2011) KSH

Szemerszki, M (2003): A magán felsőoktatás kialakulása Magyarországon, PhD értekezés (The development of private higher education in Hungary, $\mathrm{PhD}$ Thesis 2003)

Szemerszki, M (2004): Új lehetőségek a felsőoktatásban. (New chances in higher education) Educatio, 1. sz. 55-66.

Vallerand, R. J., Pelletier, L. G., Blais, M. R., Brière, N. M., Senécal, C., \& Vallières, E. F. (1992): The Academic Motivation Scale: A measure of intrinsic, extrinsic, and amotivation in edication. In: Educational and Psychological Measurement WINTER 1992. 52. p. 1003-1017.

www.felvi.hu

$\underline{\text { www.mrk.hu }}$ 